\title{
Adler is right
}

\author{
LAWRENCE WEINSTEIN and JANIS SACKHOFF \\ Marymount College of Kansas, Salina, Kansas
}

\begin{abstract}
The birth order of 249 prison inmates in jail for felony, drunkenness, and miscellaneous crimes between 1977 and 1986 was examined using chi-square analysis. There were significantly more first- and last-born people (combined) in jail for each of the above three categories of crimes than there were middle-born people. These data are among the few available current evidences bearing on Alfred Adler's notion that first- and last-born children are more likely to be drunkards and criminals than are middle-born children.
\end{abstract}

Alfred Adler (1931) was one of the first psychologists to recognize the influence of birth order on the development of personality. He felt that birth order could have a dramatic effect on personality, depending on the interpretation a person gives to his/her own position in the family structure (Ansbacher \& Ansbacher, 1956). Adler made the statement that firstborns are the most likely to be criminals and drunkards, with the last-borns following a close second (Ansbacher \& Ansbacher, 1956). Although Vockell, Felker, and Miley (1973) compiled the results of 272 experimental studies performed between 1967 and 1971 relating to Adler's various tenets, there appears to be little current research on Adler's prediction that first- and last-born individuals are more likely to become lawbreakers than are middle-born children. Therefore, we attempted to obtain information relevant to Adler's prediction concerning the relationship between birth order and criminality and drunkenness.

\section{METHOD}

Thirty-one inmates from three county jails in Northern and Central Kansas, who had been arrested for miscellaneous crimes, were asked to complete a questionnaire. One question concerned birth order. In addition, 218 Mitchell County Jail arrest records from 1977 to 1986 were reviewed. Of these 218 arrests, 34 were for felonies and 184 were for drunk driving. In summary, there were 184 inmates arrested for drunken driving, 34 people arrested for felonies, and 31 inmates currently serving time for miscellaneous crimes. Birth order was established for each individual.

\section{RESULTS}

The data for the 31 inmates (22 first- and last-borns combined and 9 middle-borns) arrested for miscellaneous crimes were analyzed by one-way chi-square analysis $\left(\chi^{2}=5.45, p<.05\right)$. Furthermore, a chi-square analysis was performed on the number of first- and last-

Requests for reprints should be sent to Lawrence Weinstein, Department of Psychology, Marymount College of Kansas, P.O. Box 5050, Salina, KS 67401. borns combined versus middle-borns for drunkenness $\left(\chi^{2}=9.58, p<.05\right)$. The number of first- and lastborns combined was 113, and the number of middle-borns was 71 . Finally, a chi-square analysis was performed on the number of inmates convicted for felonies (from 1977 to 1986) who were first- and last-borns combined versus the number of inmates who were middle-borns $\left(\chi^{2}=11.76, p<.05\right)$. The number of first- and lastborns was 27 and the number of middle-borns was 7 . In summary, there were significantly more first- and lastborn inmates who were arrested for miscellaneous crimes, for drunkenness, and for felonies.

\section{DISCUSSION}

The current data support Adler's notion that first- and last-borns have the greatest potential for developing problematic behaviors. Adler contends that, despite similarities in the home environment, siblings develop unique psychological differences because of their own interpretations of their positions in the family structure. These interpretations can manifest themselves in criminal behavior or drunkenness. A home environment that encourages security and affection for each individual child could prove advantageous for society as a whole. Therefore, with an increased awareness and understanding of the importance that chronological positions make in personality development, overall crime and drunkenness rates could decrease dramatically.

The present study combined data for first- and last-borns because Adler makes no clear distinction between the difference in probability of arrest for firstborns or last-borns. Future research should examine birth order as it affects criminality. Although Adler is not clear about how much more probable it is that firstborns will become criminals than lastborns, it seems that firstborns have some greater chance of being involved in breaking the law than do last-borns (Ansbacher \& Ansbacher, 1956).

\section{REFERENCES}

AdLER, A. (1931). What life should mean to you. Boston: Little Brown. ANSBACHER, H. L., \& ANSBACHER, R. R. (Eds.). (1956). The individual psychology of Alfred Adler. New York: Basic Books.

Vockell, E. L., Felker, D. W., \& Miley, C. H. (1973). Birth order literature 1967-71: Bibliography and index. Journal of Individual Psychology, 29, 39-53.

(Manuscript received for publication November 24, 1986.) 